Canadian

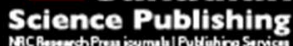

Applied Physiology, Nutrition, and Metabolism Physiologie appliquée, nutrition et métabolisme

\title{
ANGIOTENSIN-CONVERTING ENZYME (ACE-I/D) POLYMORPHISM FREQUENCY IN BRAZILIAN SOCCER PLAYERS
}

\begin{tabular}{|r|l|}
\hline Journal: & Applied Physiology, Nutrition, and Metabolism \\
\hline Manuscript ID & apnm-2015-0514.R4 \\
\hline Manuscript Type: & Brief communication \\
\hline Date Submitted by the Author: & 29-Jan-2016 \\
\hline Complete List of Authors: & $\begin{array}{l}\text { Coelho, Daniel; Federal university of Ouro Preto, } \\
\text { Pimenta, Eduardo; School of Physical Education, Physiotherapy and } \\
\text { Occupational Therapy, Federal University of Minas Gerais } \\
\text { Rosse, Izinara; Laboratory of Human and Medical Genetics, Department of } \\
\text { General Biology - Institute of Biological Sciences , Federal University of } \\
\text { Minas Gerais } \\
\text { Veneroso, Christiano; Federal University of Maranhão } \\
\text { Pussieldi, Guilherme; Federal University of Viçosa - Campus Florestal, } \\
\text { Florestal, Minas Gerais, Brazil } \\
\text { Becker, Lenice; Federal University of Ouro Preto, Minas Gerais } \\
\text { Carvalho, Maria-Raquel; Laboratory of Human and Medical Genetics, } \\
\text { Department of General Biology - Institute of Biological Sciences, Federal } \\
\text { University of Minas Gerais } \\
\text { Silami-Garcia, Emerson; Federal University of Maranhão, Department of } \\
\text { Physical Education }\end{array}$ \\
\hline Keyword: & $\begin{array}{l}\text { soccer < sports, Agiotensin-Convertin Enzyme, Gene expression, Genetic } \\
\text { selection, performance }\end{array}$ \\
\hline \multicolumn{2}{|l}{} \\
\hline
\end{tabular}


Title page

\title{
ANGIOTENSIN-CONVERTING ENZYME (ACE-I/D) POLYMORPHISM FREQUENCY IN BRAZILIAN SOCCER PLAYERS
}

\author{
Authors: \\ Coelho, Daniel Barbosa; Pimenta, Eduardo.; Rosse, Izinara Cruz; Veneroso, \\ Christiano; Pussieldi, Guilherme; Becker, Lenice Kapes; Carvalho, Maria- \\ Raquel; Silami-Garcia, Emerson.
}

\footnotetext{
Coelho, Daniel Barbosa; Becker, Lenice Kapes. Federal University of Ouro Preto,CEP-35400-000 Minas Gerais, Brazil.

Pimenta, Eduardo. School of Physical Education, Physiotherapy and Occupational Therapy, Federal University of Minas Gerais, CEP-31270-901, Minas Gerais, Brazil.

Cruz-Rosse, Izinara; Carvalho, Maria Raquel. Laboratory of Human and Medical Genetics, Department of General Biology - Institute of Biological Sciences - CEP-31270-901, Federal University of Minas Gerais, Brazil.

Pussieldi, Guilherme. Federal University of Viçosa - Campus Florestal, CEP35690-000 Florestal, Minas Gerais, Brazil.

Silami-Garcia, Emerson;. Veneroso, Christiano. Federal University of Maranhão, CEP- 65080-805, Brazil.

Corresponding Author: Coelho, Daniel Barbosa. Frei Orlando Avenue, 10351302, Caiçara, Belo Horizonte, Minas Gerais state, Brazil. E-mail: danielcoelhoc@gmailsom.9m.manuscriptcentral.com/apnm-pubs
} 


\begin{abstract}
This study aimed to analyze the angiotensin-converting enzyme (ACE-I/D) allelic and genotypic frequencies in Brazilian soccer players of different ages. The study group comprised 353 players from first-division clubs in the $U-14, U$ 15, U-17, U-20, and professional (PRO) categories. The allelic and genotypic frequencies did not differ significantly in any of the categories between the group of players and the control group. This was the first study of ACE-I/D polymorphism in Brazilian soccer players.
\end{abstract}

Keywords: Soccer; Angiotensin-Convertin Enzyme (ACE); Performance; Gene expression; Genetic selection.

[Digite texto] 


\section{Introduction}

A soccer match places great aerobic and anaerobic burdens on players of all ages (Nikolaïdis 2011), because of the number of high intensity actions involving sprints, jumps, one-to-one disputes, kicking the ball and also because of the long distances the player is required to cover in 90 minutes. Soccer is classified as an intermittent and highly intense activity (Coelho et al. 2011) and therefore performance of soccer players is directly influenced by the power, speed and strength capacities of the players.

Ahmetov et al. (2008) suggested that there might be a natural selection for high performance sports, according to the predominance of aerobic or anaerobic capacities (power, speed, strength, endurance), while in soccer all these capacities combined may be responsible for the natural selection (Gineviciene et al. 2012; Juffer et al. 2009; Eynon et al. 2014).

Among the several genes related to sports performance (Bray 2009), the gene encoding the angiotensin-converting enzyme $(A C E)$ is one of the most investigated (Zilberman-Schapira et al. 2012; Ma et al. 2013). The ACE polymorphism has been identified according to the presence (allele I) or absence (allele D) of an Alu repetition element (287 bp) in the intron 16 (rs4646994) of the ACE gene (Macarthur and North 2005).

The DD genotype is associated with performance in anaerobic activities (strength and speed) (Ahmetov et al., 2008; Collins et al., 2004; Gómez-Gallego et al., 2009; Jones and Woods, 2003; Scott, 2010). This may be due to the fact that the $D$ allele is associated with higher concentrations of ACE, which is responsible for catalyzing the conversion of ANG-I to ANG-II, leading to higher production of growth factors and hypertrophy (Alvarez, 2000). The II genotype 
was associated with performance in aerobic activities (endurance) (Alvarez, 2000; Myerson, 1999). This is due to the fact that the I allele is related to high concentrations of bradykinin, which stimulates vasodilation and blood flow promoting aerobic fitness (Macarthur \& North, 2005).

On the other hand, some studies have failed to establish a positive relationship between the ACE indel variant and sprint/power/endurance performance when Italian gymnastics athletes (Massidda et al. 2011) Ethiopian runners (Ash et al. 2011) and winter athletes (Orysiak et al. 2013) where evaluated.

Therefore, the aim of the present study was to analyze the ACE-I/D allelic and genotypic frequencies in Brazilian soccer players of different age groups.

\section{Materials and Methods}

\section{Ethical cares}

This study was approved by the Ethics in Research Committee of the Federal University of Minas Gerais (ETIC-291/09) and complied with all the norms established by the Brazilian National Health Council (Res. 466/12) regarding research with human beings. The volunteers and their representatives signed the informed written consent to participate in the experiment.

Subjects 
The participants of the study were 353 Brazilian male soccer players of different age groups: $43 \quad \mathrm{U}-14 \quad(14 \pm 0.32$ years, $69.12 \pm 7.53 \mathrm{~kg}$ and $178.21 \pm 9.72 \mathrm{~cm}) ; 68 \mathrm{U}-15(15 \pm 0.42,71.42 \pm 9.42 \mathrm{~kg}$ and $177.57 \pm 8.52 \mathrm{~cm}) ; 44 \mathrm{U}-$ $17(16 \pm 0.64$ years, $73.30 \pm 6.79 \mathrm{~kg}$ and $181.36 \pm 7.04 \mathrm{~cm}) ; 115 \mathrm{U}-20(18 \pm 0.72$ years, $73.36 \pm 7.90 \mathrm{~kg}$ and $180.65 \pm 8.20 \mathrm{~cm}) ; 83$ PRO $(23 \pm 1.67$ years, $74.25 \pm 5.79 \mathrm{~kg}$ and $182.60 \pm 8.55 \mathrm{~cm})$. Parents of all players were born in Brazil. As the Brazilian population is composed of indigenous, Africans and Europeans, it is difficult to define a Brazilian ethnicity.

All subjects played for first division Brazilian soccer clubs, meaning they were subjected to regular and specialized training sessions and participated in official national and/or international championships and tournaments for at least two years prior to the beginning of the experiments.

The categories $\mathrm{U}-15, \mathrm{U}-17, \mathrm{U} 20$ and PRO trained twice a day, two hours per training session, six days a week on the average, and the $\mathrm{U}-14$ trained only once a day. The overall training volume included the matches played.

Allele and genotype frequencies for the ACE-I/D polymorphism in the population were also established using a control group of 100 individuals $(63.32 \pm 9.51 \mathrm{~kg}$ and $165.21 \pm 9.42 \mathrm{~cm})$, randomly selected from a population of healthy Brazilian non-athletes aged 10 to 14 years who were school children, offspring of third generation Brazilians, at least.

Genotyping of ACE-I/D polymorphism

[Digite texto] 
Extraction of genomic DNA from blood samples was performed according to the protocol described in literature, using proteinase $\mathrm{K}$ followed by saline precipitation (Miller et al. 1988).

A polymerase chain reaction (PCR) method was used to genotype the ACE-I/D polymorphism (Lindpaintner et al, 1995). This method gives a 319-bp fragment when the allele $D$ (deletion) is present and a 597-bp fragment when the allele I (insertion) is present. The primer sequences were as follows: forward, 5'-GCCCTGCAGGTGTCTGCAGCATGT-3'; and reverse, 5'GGATGGCTCTCCCCGCCTTGTCTC-3'. To avoid errors in the identification of the heterozygous samples (ID) among the DD homozygous samples, a second PCR was performed with I-specific primers (specific for allele I) as follows: forward, 5'-TGGGACCACAGCGCCCGCCACTAC-3'; and reverse, 5'TCGCCAGCCCTCCCATGCCCATAA-3'. This reaction gives a 335-bp fragment when allele $\mathrm{I}$ is present, and no amplicons (bands) were created for DD homozygous samples. To identify the genotypes, DNA fragments were separated by polyacrylamide (8\%) gel electrophoresis and silver staining (Sambrook and Russel 2001).

\section{Statistical analysis}

Hardy-Weinberg Equilibrium tests were performed with the software GENEPOP v. 4.0.10. Genotypic frequencies observed for the different soccer players categories tested were compared with $\mathrm{X}^{2}$ tests implemented with the software Statistical Package for the Social Sciences for Windows ${ }^{\circledR}$, version 14.0. Significance levels were set to $p<0.05$. 


\section{Results}

Table 1 shows the genotypic and allelic frequencies observed for the ACE gene in the different groups.

\section{${ }^{* * *}$ Table 1 here ${ }^{* * *}$}

The allelic and genotypic frequencies observed indicated agreement with the Hardy-Weinberg equilibrium $(p=0.442)$.

No significant differences were found in the genotypic frequencies among the different categories for simultaneous $(p=0.85)$ or pairwise comparisons $(p=0.75)$.

The allelic and genotypic frequencies in the different groups of players were not significantly different $(p=0.45)$ from those of the control groups.

\section{Discussion}

This was the first study to investigate the ACE-I/D genotypic and allelic frequencies in Brazilian soccer players of different ages. The results revealed no differences between the different distinct age groups (categories) or between the different age groups and the control group.

In this study, the ACE-I/D frequency was analyzed in athletes of different age groups but playing the same sport, classified as a team modality (Eynon et al. 2014). Previous studies (Collins 2004; Nazarov 2001; Scanavini 2002) compared the ACE-I/D frequency between athletes from different modalities or competition levels and observed higher frequencies of the ACE-DD genotype in 
athletes specializing predominantly in individual anaerobic activities and higher frequencies of the ACE-II genotype in athletes competing in predominantly aerobic modalities compared with non-athlete control groups.

In the present study, no differences were found between the athletes and the control subjects, which suggests that the frequency of ACE is not the determining factor for success for Brazilian players. As already suggested by Eynon et al. (2014), the lack of association between genetic markers and teamsports performance could be presumably due to the mixed nature of team-sport events, in which both the aerobic and anaerobic energy systems are important factors for a successful performance. The lack of differences between age groups indicates that ACE was not an artificial selection factor of players, even though the physical requirement level is very different in different categories.

The tactical position of the players was not considered in this study. This fact could generate another statistical factor and reduce the statistical power. This fact can be considered a limitation of the study.

There have been other previous studies conducted on the evaluation of ACE-I/D genotype among soccer players. Gineviciene et al. (2012) analyzed 199 Lithuanian professional soccer players and observed higher frequencies of the ACE-ID genotype in the player groups relative to the control groups. Juffer et al. (2009) showed that among 54 professional soccer players, the frequency of the heterozygous ACE-ID genotype was higher, and the frequency of the ACE-II genotype was lower when the players were compared with long-distance runners. The findings from both studies indicate that soccer presents a mixed profile (aerobic/anaerobic), as it is a long-duration, intermittent team activity. 
Similar to what was observed in this study, Massidda et al. (2012) did not identify differences in the genotypic distribution of the ACE-I/D in a group of 30 Italian soccer players and a sample from the general population (Massidda et al. 2012). In addition, because both the control group and the athletes presented a high ACE-DD frequency (45\% and $60 \%$, respectively), the authors reported that this gene was not responsible for the success of players in activities with a mixed profile (aerobic/anaerobic), such as soccer.

A correlation between performance and ACE-I/D has not always been established, as is the case in this work, where no differences in the ACE genotypes were observed between the different player categories according to age or in comparison with the control group. Taylor et al. (1999) made the same observation with regard to no differences in the ACE genotypes among Australian athletes specializing in aerobic activities.

It has been shown that the ACE-I/D genetic distribution is $25 \%, 50 \%$, 25\% (II, ID, e DD, respectively) in the Caucasian population (Jones et al. 2002) and $23 \%, 66 \%, 11 \%$ (II, ID, e DD, respectively), in the Korean population (Oh 2007), the heterozygous ID being predominant.

Our results $(I I=17 \%$; ID $=50 \%$; e DD $=33 \%)$ are in agreement with previous studies (Gineviciene et al. 2012; Juffer et al. 2009) which found that the ACE-I/D genotype distribution of soccer players was similar to that of the general population, but they do not confirm the results by Massidda et al. (2012), who reported that the frequency of the DD genotype was predominant in both athletes and controls.

\section{Conclusions}

[Digite texto] 
It is well known from previous studies that soccer is a sport characterized by a mixed (aerobic/anaerobic) metabolic profile, and that it is also highly dependent on the players' tactical and technical capabilities. However, this is the first study on ACE-I/D polymorphism of Brazilian high performance players suggesting that the ACE-I/D gene might not play an important role on the players' overall performance capacity.

Financial support: CNPq., CAPES, FAPEMIG and PROPP-UFOP

Acknowledgements: We are grateful to Elias José de Sales Filho and Marcilene Honorato Pires for their technical and laboratory assistance.

\section{Conflicts of interest}

The authors have no conflict of interest to declare with regard to the present work.

[Digite texto] 


\section{References}

Ash, G., Scott, R., Deason, M., Dawson, T.,Wolde, B., Bekele, Z., et al. 2010. No Association between ACE Gene Variation and Endurance Athlete Status in Ethiopians. Med. Sci. Sports Exerc. 43(4): 590-597. DOI: 10.1249/MSS.0b013e3181f70bd6.

Ahmetov, I.I., Popov, D.V., Astratenkova, I.V., Druzhevskaya, A.M., Missina, S.S., Vinogradova, O.L., et al. 2008. The use of molecular genetic methods for prognosis of aerobic and anaerobic performance in athletes. Hum. Physiol. 34(3): 338-342. DOI: 10.1134/S0362119708030110

Alvarez, R., Terrados, N., Ortolano, R., Iglesias-Cubero, G., Reguero, J., Batalla, A., et al. 2000. Genetic variation in the renin-angiotensin system and athletic performance. Eur. J. Appl. Physiol. 82: 117-20. PMID: 10879452

Bray, M.S., Hagberg, J.M., Perusse, L., Rankinen, T., Roth, S.M., Wolfarth, B., et al. 2009. The human gene map for performance and health-related fitness phenotypes: the 2006-2007 update. Med. Sci. Sports Exerc. 41: 34-72. PMID:19123262

Coelho, D.B., Mortimer, L.A., Condessa, L.A., Morandi, R.F., Oliveira, B.M., Marins, J.C.B., et al. 2011. Intensity of real competitive soccer matches and differences among player positions. Rev. Bras. Cineantropom. Desempenho Hum. 13(5): 341-47. DOI: 10.5007/1980-0037.2011v13n5p341.

Collins, M., Xenophontos, S.L., Cariolou, M.A., Mokone, G.G., Hudson, D.E., Anastasiades, L., et al. 2004. The ACE gene and endurance performance during the South African Ironman Triathlons. Med. Sci. Sports Exerc. 36(8): 1314-20. DOI:10.1249/01.MSS.0000135779.41475.42. 
Eynon, N., Banting, L.K., Ruiz, J.R., Cieszczyk, P., Dyatlov, D.A., MaciejewskaKarlowska, A, et al. 2014. ACTN3 R577X polymorphism and team-sport performance: a study involving three European cohorts. J. Sci. Med. Sport. 17(1): 102-6. doi: 10.1016/j.jsams.2013.02.005

Gineviciene, V., Jakaitiene, A., Tubelis, L., Kucinskas, V. 2012. Variation in the ACE, PPARGC1A and PPARA genes in Lithuanian football players. Eur. J. Sports Sci. 14: 1-7. doi: 10.1080/17461391.2012.691117

Gómez-Gallego, F., Santiago, C., González-Freire, M., Muniesa, C.A., Fernández, M., Pérez, M. et al. 2009. Endurance performance: genes or gene combinations? Int. J. Sports Med. 30(1): 66-72. doi: 10.1055/s-2008-1038677 Jones, A., Montgomery, H.E., Woods, D.R. 2002. Human performance: a role for the ACE genotype? Exerc. Sports Sci. Rev. 30(4): 184-90. PMID:12398116 Jones, A., Woods, D.R. 2003. Skeletal muscle RAS and exercise performance. Int. J. Biochem. Cell. Biol. 35(6): 855-66. PMID:12676172.

Juffer, P., Furrer, R., González-Freire, M., Santiago, C., Verde, Z., Serratosa, L., et al. 2009. Genotype distributions in top-level soccer players: a role for ACE? Int. J. Sports Med. 30(5): 387-92. doi: 10.1055/s-0028-1105931. PMID:19277943.

Lindpaintner, K., Pfeffer, M., Kreutz, K., Stampfer, M., Grodstein, F., LaMotte, F., et al. 1995. A Prospective Evaluation of an Angiotensin-Converting-Enzyme Gene Polymorphism and the Risk of Ischemic Heart Disease. N Engl J Med. 332(11): 706-11.

Ma, F., Yang, Y., Li, X., Zhou, F., Gao, C,. Li, M., et al. 2013. The association of sport performance with ACE and ACTN3 genetic polymorphisms: a systematic 
review and meta-analysis. PLoS ONE. 8(1): e54685. doi:10.1371/journal.pone.0054685. PMID:23358679

Macarthur, D., North, K. 2005. Genes and human elite athletic performance. Hum. Genet. 116(5): 331-339. PMID:15726413

Massidda, M., Corrias, L., Scorcu, M., Vona, G., Calò, M. 2012. ACTN-3 and ACE genotypes in elite male Italian athletes. Anthropol. Rev. 75: 51-9. DOI $10.1186 / s 40798-015-0008-x$

Massidda, M., Vona, G., Caló, C. 2011. Lack of association between ACE gene insertion/deletion polymorphism and elite artistic gymnastic performance of Italian gymnasts. Eur J Sport Sci. 11(3). DOI:10.1080/17461391.2010.499971

Miller, A.S., Dykes, D.D., Poleski, H.F. 1988. A simple salting out procedure for extracting DNA from human cells. Nucl. Acid. Res.16(3):1215. PMID:3344216 Myerson, S., Hemingway, H., Budget, R., Martin, J., Humphries, S., Montgomery, H. 1999. Human angiotensin I-converting enzyme gene and endurance performance. J. Appl. Physiol. 87(4): 1313-6. PMID:10517757

Nazarov, I.B., Woods, D.R., Montgomery, H.E., Shneider, O.V., Kazakov, V.I., Tomilin, N.V., et al. 2001. The angiotensin-converting enzyme I/D polymorphism in Russian athletes. Eur. J. Hum. Genet. 9(10): 797-801. PMID:11781693

Nikolaïdis, P. 2011. Anaerobic power across adolescence in soccer players. Hum. Move. Sci. 12: 342-7.

Oh, S. 2007. The distribution of I/D polymorphism in the ACE gene among Korean male elite athletes. J. Sports Med. Phys. Fitness. 47(2)-250. PMID:17557068

Orysiak, J., Zmijewski, P., Klusiewicz, A., Kaliszewski, P., MalczewskaLenczowska, J., Gajewski, J., et al. 2013. The association between ace gene 
variation and aerobic capacity in winter endurance disciplines. Biol. Sport. 30: 249-253. DOI:10.5604/20831862.1077549

Sambrook, J., Russel, D.W. 2001. Molecular cloning: a laboratory manual. 3rd ed. New York: Cold Spring Harbor Laboratory.

Scanavini, D., Bernardi, F., Castoldi, E., Conconi, F., Mazzoni, G. 2002. Increased frequency of the homozygous II ACE genotype in Italian Olympic endurance athletes. Eur. J. Hum. Genet. 10(10): 576-577. PMID:12357325

Scott, R.A., Irving, R., Irwin, L., Morrison, E., Charlton, V., Austin, K., et al. 2010. ACTN3 and ACE genotypes in elite Jamaican and US sprinters. Med. Sci. Sports. Exerc. 42(1): 107-112. doi: 10.1249/MSS.0b013e3181ae2bc0. PMID:20010124

Taylor, R., Mamotte, C.D., Fallon, K., Bockxmeer, F.M. 1999. Elite athletes and the gene for angiotensin-converting enzyme. J. Appl. Physiol. 87(3): 1035-7. PMID:10484574

Zilberman-Schapira, G., Chen, J., Gerstein, M. 2012. On sports and genes. Recent Pat. DNA Gene Seq. 6(3): 180-8. PMID:22762737

[Digite texto] 


\section{Tables:}

Table 1: Genotypic and allelic frequencies in absolute (n) and relative (\%) values observed for the ACE locus in the control (CON), U-14, U-15, U-17, $\mathrm{U}-20$, and professional (PRO) groups:

\begin{tabular}{lccccccc}
\hline & \multicolumn{3}{c}{ Genotypic, $n(\%)$} & & \multicolumn{2}{c}{ Allelic, $n(\%)$} \\
\cline { 2 - 4 } \cline { 6 - 7 } Groups & DD & ID & II & & D & I \\
\hline CON & $28(0.28)$ & $53(0.53)$ & $19(0.19)$ & & $109(0.55)$ & $91(0.45)$ \\
U-14 & $13(0.30)$ & $22(0.51)$ & $8(0.19)$ & & $48(0.56)$ & $38(0.44)$ \\
U-15 & $15(0.22)$ & $40(0.58)$ & $14(0.20)$ & & $70(0.51)$ & $68(0.49)$ \\
U-17 & $17(0.39)$ & $18(0.41)$ & $9(0.20)$ & & $52(0.59)$ & $36(0.41)$ \\
U-20 & $28(0.27)$ & $55(0.53)$ & $21(0.20)$ & & $111(0.53)$ & $97(0.47)$ \\
PRO & $30(0.33)$ & $45(0.50)$ & $15(0.17)$ & & $105(0.58)$ & $75(0.42)$ \\
\hline
\end{tabular}

[Digite texto] 